Acta Biologica Plantarum Agriensis 5(1): 35 (2017) ISSN 2061-6716 (Print), 2063-6725 (Online) http://abpa.ektf.hu/
DOI:10.21406/abpa.2017.5.1.35

$4^{\text {th }}$ CC 2017 Abstract Lecture

\title{
CURRENT RESUlTS OF BRYOPHYTE MAPPING OF BöRZSÖNY MTS (HUNGARY)
} A Börzsöny hegység mohatérképezésének aktuális eredményei

\author{
József NAGY ${ }^{1} \&$ Peter ERZBERGER ${ }^{2}$
}

\begin{abstract}
${ }^{1}$ Szent István University, Faculty of Horticultural Science, Department of Botany and Soroksár Botanical Garden, H-1118 Budapest, Villányi út 29-43., Hungary; ${ }^{2}$ D-10823 Berlin, Belziger Str. 37, Germany; e-mail: Nagy.Jozsef@kertk.szie.hu
\end{abstract}

In 1966, about half a century ago, László Vajda published his account of the Börzsöny Mts ( $A$ Börzsöny-hegység mohaflórája), in which he reports data on 316 bryophyte species, the results of his exploration of the region in cooperation with Ádám Boros. Later Orbán \& Vajda (1983) mention another 9 species from this area. Around this time there is an intermission in the systematic bryofloristic research of the Börzsöny Mts. In the 1990-s, P. Erzberger and B. Papp took up again the bryological exploration of the area. At present, systematic recording is carried out in 19 grid cells of the Central European Mapping Scheme (KEF). 7 squares lie nearly completely in the mountain region, whereas 12 squares belong in part to neighbouring landscapes. As a consequence of systematic grid-cell based recording, research is also carried out in formerly neglected parts of the region. During our field work we focus on some formerly underexplored special sites (e.g. abandoned quarries, wetlands) and outcrops of locally rare bedrock (peripheral loess deposits, tertiary limestone). In the case of some moss genera (Bryum, Fissidens, Grimmia, Racomitrium, Schistidium) which were revised by P. Erzberger, collection of herbarium data in the Botanical Department of the Hungarian Natural History Museum preceded the field work. Results: In the 19 mapped grid cells taken together, we collected more than 3000 recent floristic data in a database. This corresponds to nearly 2000 localized data points, of which more than 1800 fall within the range of the mountains. The number of taxa in square 8079.2 (Királyháza) exceeds 200. More than 150 taxa each were recorded from 8079.1 (Perőcsény) and 8079.4 (Nagy-Hideg-hegy). The number of taxa which were first recorded after 1990 in the Börzsöny Mts exceeds 75. Among them three taxa are new to Hungary: Fissidens crispus (8079.2) was found by herbarium revision, whereas Brachythecium curtum (8079.4) and Crossidium squamiferum var. squamiferum (8279.2) were detected during field work. Further remarkable taxa first documented include Anacamptodon splachnoides (Endangered EN), Bryum archangelicum (Data deficient DD), Bryum intermedium (DD), Bryum mildeanum (DD), Dicranum viride (Vulnerable VU), Fabronia pusilla (EN), Fissidens arnoldii (VU), Fissidens bambergeri (Not Evaluated NE), Frullania inflata (EN), Grimmia decipiens (EN), Grimmia lisae (VU), Jungermannia atrovirens (DD), Pseudoleskea saviana (DD-va), Pyramidula tetragona (EN), Racomitrium aciculare (DD), Racomitrium affine (DD), Rhynchostegiella curviseta var. laeviseta (NE), Rhynchostegiella teneriffae (VU), Syntrichia caninervis var. gypsophila (DD). On the other hand, at present there are about 75 species (29 liverworts and 46 mosses) reported in the accounts of Vajda (1966) and Orbán \& Vajda (1983) of which we have not yet found extant occurrences. 